and in 1944 joined the Ministry of Supply team, headed by Dr M. Dixon, working at Cambridge on the actions of war gases on enzymes. When the team was disbanded, he was appointed to a lectureship in the Department of Biochemistry at the University of Cambridge and continued there until the move to Babraham in 1959.

Greville's main contributions were in the field of mitochondrial metabolism and the action of "uncoupling", drugs. His first biochemical studies were carried out in collaboration with F. Dickens and dealt with sugar conversions and breakdown in embryonic, tumour and adult normal tissues. In 1933 he began, with E. C. Dodds, an investigation of the metabolic stimulation produced by dinitrophenol, and that led on to a study of "uncoupling", drugs that formed the subject of his $\mathrm{PhD}$ thesis and became an interest that continued throughout the rest of his life. In the early 1950 s improved methods made possible tho preparation of mitochondria and more direct investigation of their metabolic activities. In collaboration with A. L. Lehninger, Greville showed that both $\mathrm{D}$ and $\mathrm{L}-\beta$-hydroxybutyrate undergo oxidation in mitochondria although the L-isomer was thought to be the "naturally occurring" form. The initial paths of oxidation of the two forms were found to be different, but it seemed that the $\mathrm{D}$-form also occurred naturally and played a part in ketone body and fatty acid metabolism.

In 1955 Greville and D. M. Needham showed that dinitrophenol accelerates the ATPase activity of both myosin and mitochondria and, from 1956, Greville began a collaboration with J. B. Chappell on mitochondrial swelling. They established that the swelling induced by a variety of agents, for example phosphate, thyroxino and calcium ions, was dependent on respiration and a supply of energy. After moving to Babraham in 1959, Greville continued to work on the biochemistry and morphology of mitochondria: Important studies were made of the influence of the composition of the suspending medium on the properties of these organelles and the mechanism by which they accumulate divalent metal ions. In collaboration with E. A. Munn, he isolated a new protein, for which the name calliphorin has been proposed, from mitochondria of the flight muscles of Calliphora erythracephala. Calliphorin has been purified to a single component and, together with related proteins, seems to be an important storage substance fairly widely distributed among the insect orders.

Everyone who has known or worked with Greville pays tribute to the immonse care and patience he exercised in his experimental work and the meticulous repetition used to ensure the accuracy of his observations. He spent a large part of his time helping other people with their research work, but was so self-effacing that many of theso contributions went unacknowledged. His long experience and critical attitude made him an invaluable source of information and in recent years he wrote many noteworthy reviews on mitochondrial biochemistry. An endeavour to which he recently devoted much time and care has been his co-editorship with P. N. Campbell of Essays in Biochemistry on behalf of the Biochemical Society. Authors contributing essays have been somewhat staggered to find that the Editor had checked every reference in lists frequently running to several hundred. At the time of his death, Greville was actively working on the sixth volume of this immensely successful series which is widely read for both pleasure and profit by advanced students and established workers in biochemistry.

Greville worked in a field in which there has been much controversy and moved among workers between whom deep and sometimes bitter disagreements had arisen. His balanced viewpoint here was highly regarded throughout tho scientific world. It is characteristic of his modesty and humour that when asked to scrutinize Mitchell's chemiosmotic hypothesis of respiratory chain and photosynthetic phosphorylation he introduced this as follows:

"The present writer when asked for a bird's eye appraisal of the Mitchell hypothosis felt that tho wrong phylum had been selected, and he offers instead a worm's eve scrutiny. His chief qualifications are that he is completely uncommitted and likely to bo psychologically satisfactory, since he is on excellent terms with those of the protagonists whom he happens to know."

\section{Dr I. A. Galloway}

IAN Galloway, director of the Animal Virus Research Institute at Pirbright in Surrey from 1939 to 1963 , died suddenly on December 22, 1969. He had been the leading figure in foot and mouth disease research in Britain for many years and was responsible for the major develop. ment of the laboratory at Pirbright and for the research programme which has given it its high international reputation in the field of foot and mouth disease.

Galloway was born in Edinburgh in 1900 and educated at George Heriot's School and the Royal (Dick) School of Veterinary Studies, obtaining his membership of the Royal College of Veterinary Surgeons in 1922 and his BSc the following year. His early training in research was at the Institut Pasteur, where he entered the service of Professor Levaditi. Galloway returned to England in 1926 to work at the National Institute for Medical Research at Hampstead on behalf of the Foot and Mouth Disease Researeh Committee. He was at Hampstead until 1939, when it was decided to appoint a scientific superintendent to the research station operated by the committec at Pirbright. Galloway remained at Pirbright for twenty-four years, during which he transformed the research station from a small field unit into a well equipped institute for virological research.

Galloway's contribution must be seen against the enormous changes in virological research which occurred during his career. In the early 1920s much effort was devoted to the search for experimental animals to avoid expensive experimentation in the natural hosts. Galloway's first publication recorded the pathogenicity of foot and mouth disease virus for the rabbit, a host which, although susceptible, was never destined to supplant the guinea-pig in this field. In Paris Galloway had become interested in the problem of the size and physical charac teristics of the virus; at Hampstead he and W. A.J. Elford began studies of virus size based on ultrafiltration analysis and later on ultracentrifugation. Their findings, which gave values of 8-12 $\mathrm{nm}$ by filtration and $20 \mathrm{~nm}$ by centrifugation, were not widely different from those determined twenty or more years later by more refined techniques.

The facilities at Pirbright in 1939 were a challenge to Galloway, allowing him to scale up his work and make use of the farm animal instead of the guinea-pig. He insisted that, if results of value were to be obtained (for example) in vaccination experiments, adequate numbers of cattle should be omployed to give statistically significant results and, stimulated by him, methods for accurate assay of the virus and for the estimation of immunogenic potency of vaccines were developed during the $1940 \mathrm{~s}$. Comparison of vaccines of different strains within one general immunological type brought to light hitherto unsuspected differences. Papers from the institute published in 1949 showed the importance of subtype differences in immunization programmes, and this work has influenced the practical application of foot and mouth disease vaccines all over the world.

By his personal contacts overseas, Galloway stimulated an interest in dealing with foot and mouth disease in underdeveloped countries, first of all by surveying the strains of virus that were present. This work led to the discovery of three new types in Africa in the late 1940s and a further type in Asia in 1955. The survey work established by Galloway became so obviously valuable that its continuance was guaranteed by the establishment at 
Pirbright of the World Reference Laboratory for Foot and Mouth Disease in 1957.

Under his direction in the 1950s the institute developed many new techniques, notably in tissue culture, and Galloway was able to encourage the development of more advanced work in the biochemistry and biophysics of the virus which he himself had been associated with twenty years earlier, with Elford.

Galloway took a leading part in much international discussion on the control of foot and mouth disease. $\mathrm{He}$ advised the US Government in 1946-47 on the campaign against the outbreak in Mexico and was responsible for founding the Technical Group of the European Commission for the Control of Foot and Mouth Disease. Through these international activities it can be fairly claimed that he helped greatly towards the cooperation which has achieved a reduction of the disease in many of the most seriously affected areas.

He is survived by his wife, one son and two daughters.

\section{Correspondence}

\section{Sternglass's Assumptions}

SIR,-The letter under the above title by P. L. Taylor (Nature, 225, 881; 1970) is an example of arguing in a circle. He proves that infant mortality is an exponential function of time by making the assumption that the overall fractional rate of change is constant!

As we have stated in our paper (Nature, 224, 1257; 1969), there is no justification for such an assumption. Even if we postulated an exponential dependence for each individual cause of death, it would not be true for the total mortality, since the different causes of infant mortality are reduced at different rates. Indeed, there is at least one cause, due to genetic defects, which is either irreducible or can only be reduced extremely slowly. Thus a plot of the logarithm of total mortality against time would give a curve with a gradually decreasing slope and not a straight line.

$$
\begin{aligned}
& \text { Yours faithfully, } \\
& \text { PATRICIA J. LINDOP } \\
& \text { J. Rotblat }
\end{aligned}
$$

Department of Physics,

The Medical College of St Bartholomew's Hospital, Charterhouse Square, London EC1.

\section{Information Explosion}

SIR,-I hope that the scientific community will heed Professor Webb's warning (Nature, 225, 132; 1970) that we need new ways of presenting information if we are to survive the crisis brought about by the growth of the published literature.

Our colossal indifference to this basic problem stems perhaps from our belief that we can solve it by using computers. Yet this approach is obviously hopeless. Machines can retrieve information for the reader, but they cannot assimilate it for him.

If we examine the literature, we see that it is designed to save publishing costs and not to aid the reader in rapidly and easily comprehending complex information. What fundamentally we need to do then is (1) recognize that the cost of publication is an integral part of the cost of research and be prepared to pay adequate page costs and (2) redesign the literature for rapid reading and easy assimilation.

Although this program will raise the cost of publication by about 10 per cent, this increased cost will be offset by the manifold greater economic returns resulting from the increased usefulness of the information being published.

$$
\text { Yours faithfully, }
$$

$$
\text { F. BRUCE SANFORD }
$$

US Bureau of Commercial Fisheries,

Division of Publications,

Seattle, Washington 98101, USA.

\section{Keep Off the Grass}

SIR,-As mentioned in your leading article ${ }^{1}$ of February 7 , 1970 , more research is needed on cannabis, the effects of which have often been compared with those of alcohol. But a present obstacle against undertaking these highly desirable researches is the great difference between the problems of excessive alcohol consumption and those of the illegal consumption of marihuana, hashish or other cannabis products. The difference is that results obtained from biochemical, pharmacological or behavioural studies of alcohol can be correlated with the amount of alcohol circulating in the individuals under test (a good number of reliable methods of assay are available), whereas none of the results, even those of recent date ${ }^{2-4}$, can be linked with the tetrahydrocannabinols (THC), either as such or metabolized and present in the experimental subjects. This present lack of a quantitatively reliable assay of the amount of active principle or principles of cannabis, absorbed and maybe circulating in the blood or perhaps in other body fluids, makes an accurate assessment of the pharmacological or behavioural data almost meaningless, especially if such results are compared with the effects of alcohol or other drugs or obtained with control groups. May I express a strong hope that this problem of an analytical method, obviously for micro-quantities, will be solved soon, because without it there is little chance of establishing the true nature (benign or dangerous) of cannabis ?

THC may be transformed into the materials which, in fact, affect the central nervous system, and there are in any case wide individual variations in the subjective and objective effects. Moreover, illegally acquired marihuana cigarettes (as is often ignored) are usually low in their contents of active constituents, and the long-term effects of cannabis on Western man are unknown. All these uncertainties add to the great difficulty of giving unbiased judgment about the kind of harm (temporary or permanent) that abuse of the drug would bring about. This leaves the presence of tobacco, mixed with hemp particles in the pot cigarettes, outside any consideration of damage to health.

One further point merits emphasis : if one takes "harm" as measure of the degree of hardness of a drug, and not the number of habituates or addicts, then the amphetamine and barbiturate groups are surely harder than cannabis. But that alone is no recommendation to free cannabis from its legal shackles. On the contrary, without entering a large list of reasons for this viewpoint, one can only agree with the last sentence of the leader of The Times ${ }^{5}$, just as one has to agree with your leader, when it places education, information and public discussions at the top of priorities in the struggle against the problem of drug taking, and at the same level as legislation.

$$
\text { Yours faithfully, }
$$

Magnolia Cottage,

$$
\text { F. Bergata }
$$

Bel Royal,

Jersey, Channel Islands.

${ }^{1}$ Nature,225, 485 (1970).

${ }^{2}$ Weil, A. T., Zinberg, N. E., and Nelsen, J. M., Science, 162, 1234 (1968).

${ }^{3}$ Weil, A. T., and Zinberg, N. E., Nature, 222, 434 (1969).

4 Crancer, jun., A., et al., Science, 164, 851 (1969).

${ }^{5}$ Leader, and Fowler, N., The Times, February 7 (1970). 